\title{
Uwarunkowania środowiskowe procesów budowy i eksploatacji elektrowni wiatrowych „Podborze" w okolicach Ostrowi Mazowieckiej
}

\author{
Milena Brzózka \\ Wydział Filozofii Chrześcijańskiej, Uniwersytet Kardynała Stefana Wyszyńskiego w Warszawie \\ ul. Wóycickiego 1/3, 01-938 Warszawa \\ milena.k.brzozka@gmail.com・ ORCID 0000-0001-8570-3095
}

\section{Streszczenie}

W artykule przedstawione zostaną wybrane zagadnienia związane z budową i eksploatacją elektrowni wiatrowych. Punktem odniesienia będzie planowana elektrownia „Podborze” w okolicach Ostrowi Mazowieckiej. Wskazane zostaną potencjalne zasięgi i skutki oddziaływania planowanej inwestycji. Ostatnim elementem będzie wskazanie sposobów na działania profilaktyczne i przeciwdziałanie negatywnym skutkom.

\section{Słowa kluczowe}

farmy wiatrowe, odnawialne źródła energii, oddziaływanie, aspekt środowiskowy

\section{Wprowadzenie}

Gmina Ostrów Mazowiecka to gmina miejsko-wiejska, leżąca w północno-wschodnim obszarze województwa mazowieckiego, w powiecie ostrowskim. Przeważająca część terenu gminy charakteryzuje się występowaniem ekosystemów leśnych, pastwisk wraz z gruntami rolnymi oraz łąk. Szczególnie istotnym aspektem dla przyrodniczego znaczenia gminy jest jej położenie w pobliżu obszarów Natury 200o. Liczne obszary Natury $2000-$ ok. $63 \%$ powierzchni gminy (ok. 17,77 ha) - są zlokalizowane na jej terenie (Plan Gospodarki 2015: 21-24). Ponadto w pobliżu gminy znajdują się dwa obszary specjalnej ochrony ptaków „Puszcza Biała” PLB140007 oraz „Dolina Dolnego Bugu" PLB140001. Nadbużański Park Krajobrazowy i obszar mający znaczenie dla Wspólnoty „Ostoja Nadbużańska”
PLH140o11 to pobliskie, również niezwykle atrakcyjne przyrodniczo obszary mające na celu ochronę gatunkową fauny i flory. Położenie gminy ma zatem ogromny wpływ na planowane przedsięwzięcie budowy i eksploatacji farm wiatrowych „Podborze”, które w zamiarze miało powstać na przestrzeni dwóch sąsiadujących ze sobą podmiejskich miejscowości: Podborza i Ugniewa (Brzózka 2016: 5).

\section{Elektrownie wiatrowe w środowisku}

We wrześniu 2011 r. powstał raport o oddziaływaniu na środowisko przedsięwzięcia pod nazwą Zespół Elektrowni Wiatrowych „Podborze”. W dokumencie tym zostały przedstawione badania dotyczące m.in. wpływu budowy i eksploatacji elektrowni wiatrowych na otoczenie. Zgodnie z tym raportem w miejscowościach Podborze 
i Ugniewo mają być zbudowane cztery elektrownie pozyskujące energię $\mathrm{z}$ wiatru. Planowana budowa zespołu farm wiatrowych "Podborze" wraz z infrastrukturą towarzyszącą zlokalizowana będzie na gruntach ornych użytkowanych rolniczo (Raport 2011: 16). Analizując mapę topograficzną oceny oddziaływania elektrowni na środowisko i jednocześnie biorąc pod uwagę walory przyrodnicze otoczenia, usytuowanie przedsięwzięcia będzie miało miejsce w pobliżu lasów, sadów oraz łąk od kierunku wschodniego i zbiorników wodnych wraz z ciekami od południa i zachodu. Taka lokalizacja z pewnością będzie miała znaczący wpływ na siedliska zwierząt. Od strony północnoi południowo-zachodniej zamierzone przedsięwzięcie będzie sąsiadowało z podmiejską zabudową mieszkalną, głównie zagrodową z udziałem zabudowy mieszkaniowej jednorodzinnej, oraz obiektem hodowli zwierząt futerkowych, co będzie miało istotne znaczenie dla przyszłych warunków życia mieszkańców okolicy i powstałej hodowli.

\section{Zasięg i skutki oddziaływania elektrowni wiatrowych na środowisko}

Zasięg oddziaływania farm wiatrowych na środowisko dotyczy wpływu ich eksploatacji zarówno na biocenozę, jak i biotop. W przyrodzie nieożywionej bardzo ważną rolę posiada gleba, która niewłaściwie użytkowana i uprawiana może przestać przynosić obfite plony rolnikom. Lokalizacja czterech planowanych elektrowni wiatrowych na gruntach ornych przyczyni się zatem do dewastacji środowiska i degradacji gleb. Głównym zagrożeniem dla środowiska glebowego będą zanieczyszczenia odpadami powstającymi zarówno na etapie budowy, eksploatacji, jak i demontażu przedsięwzięcia. Na etapie powstawania farm wiatrowych wytworzy się wiele odpadów opakowaniowych z papieru i tektury oraz tworzyw sztucznych (Raport 2011: 44-45). Pozostanie wiele sorbentów, tkanin do wycierania oraz materiałów filtracyjnych, a także ubrań ochronnych, czyli odpadów należących do 15 grupy według „Katalogu odpadów” (Rozporządzenie 2020).
Zgodnie z rozporządzeniem oraz na podstawie wnikliwej analizy tabeli zamieszczonej w raporcie, do przewidywanych pozostałości zgromadzonych po budowie farm wiatrowych „Podborze”, zaliczających się do grupy 15 „Katalogu odpadów”, będą należały głównie opakowania z tworzyw sztucznych, których prognozowana ilość wyniesie $12 \mathrm{~m}^{3}$, oraz opakowania z papieru i tektury $-4,3 \mathrm{~m}^{3}$ i opakowania $\mathrm{z}$ drewna w ilości $2 \mathrm{~m}^{3}$ (Raport 2011). Poza tymi zgromadzonymi odpadami powstaną, w już o wiele bardziej znikomej objętości, opakowania materiałowe, metalowe i zmieszane odpady opakowaniowe. Powstałe odpady z tkanin materiałowych dotyczyć będą zużytych w pracach ścierek i szmat, które wraz z sorbentami będą stanowiły o,11 $\mathrm{m}^{3}$ objętości. Do kolejnej grupy odpadów powstałych na etapie budowy elektrowni wiatrowych będą należały odpady z grupy 17 „Katalogu odpadów”, czyli pozostałości z remontów, budowy i demontażu obiektów budowlanych wraz z infrastrukturą drogową, włączając glebę i ziemię z terenów zanieczyszczonych. W skład 17 grupy odpadów powstałych na etapie budowy czterech elektrowni wiatrowych „Podborze” będą wchodziły głównie gleba i ziemia, łącznie z kamieniami, w ilości około $4000 \mathrm{~m}^{3}$ objętości, w tym z wykopu pod linię kablową SN $15 \mathrm{kV}$ i fundamenty obiektów budowlanych - $2400 \mathrm{~m}^{3}$ oraz żelazo i stal - o,64 t, a także odpowiednio: kable - $93 \mathrm{mb}$, odpady betonu oraz gruz betonowy z rozbiórek i remontów w ilości $5,5 \mathrm{~m}^{3}$, odpady z materiałów ceramicznych i elementów wyposażenia - o,4 $\mathrm{m}^{3}$, zmieszane odpady $\mathrm{z}$ betonu i materiałów ceramicznych $-0,8 \mathrm{~m}^{3}$ oraz drewno, tworzywa sztuczne, odpadowa papa, złomy metaliczne i stopy metali, a także materiały izolacyjne (Brzózka 2016).

Z powyższej analizy wynika, iż zanieczyszczenie gleb odpadami na etapie budowy siłowni wiatrowych będzie dotyczyło głównie odpadów należących do 17 grupy Katalogu. Dla porównania, możliwe rodzaje odpadów powstałych na etapie eksploatacji zespołu farm wiatrowych „Podborze” dotyczą głównie sorbentów, materiałów filtracyjnych oraz 
tkanin do wycierania i ubrań ochronnych zanieczyszczonych substancjami niebezpiecznymi wraz z zużytymi urządzeniami zawierającymi elementy niebezpieczne, których łączna przewidywana ilość wyniesie ok. $30 \mathrm{~kg}$. Oprócz nich powstaną także odpady pochodzące z opakowań i zużytych olejów silnikowych, powstałych podczas konserwacji elementów elektrowni. Możliwymi olejami odpadowymi będą mineralne oleje hydrauliczne niezawierające związków chlorowcoorganicznych oraz mineralne oleje silnikowe, przekładniowe i smarowe niezawierające związków chlorowcoorganicznych oraz pozostałe oleje przekładniowe i smarowe w łącznej objętości ok. $4 \mathrm{~m}^{3}$ (Raport 2011). Zatem podczas użytkowania farm wiatrowych i ich dwudziestopięcioletniej eksploatacji istnieje zagrożenie zanieczyszczenia powierzchni ziemi substancjami niebezpiecznymi i olejami, które mogą wpłynąć na wyjałowienie gleb, a w następstwie na ich późniejszą nieużyteczność.

Analizując zestawienie obrazujące powstawanie odpadów na etapie demontażu i likwidacji elektrowni, najwięcej niepotrzebnych odpadów powstanie z materiałów i elementów budowlanych wraz z infrastrukturą drogową, do których zaliczają się odpady betonowe, gruz betonowy z rozbiórek i remontów w ilości ok. $2400 \mathrm{~m}^{3}$ oraz odpady z remontów i przebudowy dróg - ok. $368 \mathrm{~m}^{3}$. Oprócz nich powstaną również odpady z tworzyw sztucznych pochodzących z demontażu łopat wirnika - prognozowana ilość odpadów z tworzyw sztucznych wyniesie ok. 50 ton - oraz z żelaza i stali z rozbiórki gondoli, piast i wieży elektrowni w ilości ok. 1616 ton (gdyż jedna elektrownia zawiera ok. 350 ton żelaza i stali - (Raport 2011: 72-73). Równie istotnymi elementami, które pozostawią po demontażu wiele odpadów, będą kable, których przewidywana do zużycia ilość wyniesie prawdopodobnie ok. $11680 \mathrm{mb}$. Zanieczyszczenia gleb mogą pozostawić po sobie również odpady z materiałów ceramicznych i elementów wyposażenia - ok. $3 \mathrm{~m}^{3}$, a także materiały izolacyjne - ok. 3,5 $\mathrm{m}^{3}$.
Wpływ zanieczyszczenia gleby substancjami wymienionymi powyżej oraz poruszenie ziem przyczyni się do degradacji gleb i wysiedlenia zwierząt, na skutek pogorszenia ich warunków życia i utraty miejsc naturalnego bytowania w glebie, co spowoduje konieczność ponownego poszukiwania siedlisk przez zwierzęta i zaburzenie różnorodności biologicznej na danym obszarze. Istotny jest również negatywny wpływ zużytych olejów odpadowych na żyzność gleb. Najwyższy stopień zanieczyszczenia gleb mogą spowodować oleje wykorzystywane przy konserwacjach obiektów i ich eksploatacji. Szkodliwe działanie zużytych olejów smarowych na powierzchnie gleb może spowodować toksyczność i zatrucie ziem, a także wód gruntowych znajdujących się w pobliżu przedsięwzięcia (Web-01). Zdaniem mgr inż. Haliny Syrek oleje odpadowe przyczyniają się do zmian w mikrobiologicznej strukturze ziemi, działają negatywnie w sposób mutagenny na organizmy bakteryjne oraz hamują produkcję fitoplanktonu (Web-o1). W ten sposób moga zostać skażone liczne gatunki fauny i flory danego obszaru, które w następstwie będą przenosiły zanieczyszczenia (szczególnie $\mathrm{PCB}^{1}$ ) na pozostałe czyste obszary środowiska, dlatego niezwykle ważnym działaniem jest odpowiednie postępowanie z odpadami, w szczególności z odpadami niebezpiecznymi powstałymi na etapie eksploatacji siłowni wiatrowych.

Nie tylko jednak odpady są groźne dla środowiska. Skutki pracy elektrowni wiatrowych niosą ze sobą także inne formy zagrożeń dla środowiska naturalnego. Jednym z nich jest emisja hałasu do otoczenia. Hałas może być postrzegany jako zasadniczy problem, będący negatywnym rezultatem działania farm wiatrowych, oddziałujący niekorzystnie na warunki życia mieszkańców

1 PCB - polichlorowane bifenyle - to stabilne, niereaktywne lepkie ciecze o małej lotności, których używasię jako płynów hydraulicznych, płynów chłodząco-izolujących w transformatorach i plastyfikatorów w farbach (definicja wg tłumaczenia Mirosława Nakoniecznego, w: Hopkin et al 2002: 12). 
obszaru usytuowania projektowanych obiektów siłowni wiatrowych. Za potwierdzenie powyższej tezy można uznać opublikowane w recenzowanych czasopismach wyniki zagranicznych badań naukowych, ukazujące prawdziwe realia życia społeczeństwa zmagającego się ze swoim utrapieniem. Posiłkując się wyżej wspomnianymi badaniami, wskazane jest nawiązanie do ich przesłania. Odnoszą się one bowiem do opisu przedstawiającego wpływ emisji hałasu na warunki egzystencji miejscowej ludności. W artykule (van den Berg 2004: 955-956) został ukazany wpływ profilu wiatru nocą na dźwięk turbiny wiatrowej. Osiedlona w niedalekim sąsiedztwie turbin wiatrowych (ok. $1900 \mathrm{~m}$ ) miejscowa ludność stopniowo zaczęła skarżyć się na ogólne rozdrażnienie i zaburzenia w codziennym funkcjonowaniu. Niepokojące dolegliwości szczególnie nasilały się późnym wieczorem i nocą (van den Berg 2004). Dlaczego zatem usytuowanie elektrowni wiatrowych w dopuszczalnych odległościach stało się nieadekwatne do rzeczywistych pomiarów i skutków ich eksploatacji na życie mieszkańców? Według przeprowadzonych przez specjalistów badań oceny nad hałasem pochodzącym z turbin wiatrowych, prowadzonych w optymalnych warunkach w porze dziennej i nocnej, obliczenia dotyczące poziomu dźwięku różnią się między sobą w zależności od pory dnia i zastosowanej metody mierzalnej. W związku z powyższym metoda mierzalna oparta o logarytmiczny profil wiatru okazała się być niekoniecznie dokładnym miernikiem i wyznacznikiem odpowiedniej odległości lokalizacji farm wiatrowych od zabudowań mieszkalnych. Badanie ukazało różnicę $18 \mathrm{~dB}$ skali dźwięku między porą nocną a dzienną (van den Berg 2004). Okazało się, że najbardziej uciążliwe dla mieszkańców są dźwięki pulsowania, a wręcz dudnienia obracających się turbin w porze nocnej z częstotliwością jednego uderzenia na sekundę. Dźwięk odległych ok. $2 \mathrm{~km}$ od zabudowań siłowni wiatrowych spowodował irytację mieszkańców i liczne skargi z nią związane. Miejscowa ludność porównała ich odgłos do odległego echa przypominającego dźwięk wbijania pala w ziemię.

Z pojęciem emisji hałasu ściśle wiąże się zjawisko emisji ultra- i infradźwięków, czyli niesłyszalnych na pozór dla ludzkiego ucha dźwięków, mających związek z pracą elektrowni wiatrowych, ale oddziałujących na środowisko i prowadzących do wielu konsekwencji zdrowotnych mieszkańców okolicy. Dowodem naukowym uzasadniającym wpływ infradźwięków na samopoczucie społeczeństwa może być artykuł, którego celem było ukazanie wpływu hałasu na samopoczucie dzieci z pobliskich szkół zlokalizowanych w pobliżu farm wiatrowych. Dowiedziono, iż wpływ eksploatacji wiatraków negatywnie oddziałuje na stan badanych osób, powodując zmęczenie, znużenie, osłabiając koncentrację dzieci i zaburzając ich zdolność do samodzielnego myślenia w trakcie nauki (Bronzaft 2011: 291-294). Mając na uwadze powyższe dane pochodzące $\mathrm{z}$ wyników przeprowadzonych zagranicznych badań, należy ponownie dokładnie rozważyć usytuowanie planowanego projektu budowy zespołu elektrowni wiatrowych "Podborze” o dopuszczalnej mocy akustycznej 106,5 dB. Pomiary odległości zaprojektowanych turbin wiatrowych ukazane na mapie topograficznej obszaru przeznaczonego pod ich budowę w miejscowości Ugniewo (Raport 2011: zał. 1), nieopodal miasta Ostrów Mazowiecka, przedstawiają bliską lokalizację turbin wiatrowych od zabudowy mieszkalnej, z przeważającą częścią zagrodowej, z udziałem zabudowy mieszkaniowej jednorodzinnej: $1024 \mathrm{~m}$ na północ, $1340 \mathrm{~m}$ w kierunku północno-zachodnim, w pobliżu obwodnicy miasta Ostrów Mazowiecka, 1190 m w kierunku zachodnim oraz $1100 \mathrm{~m}$ na południe od zlokalizowanej stadniny koni. Poza tymi zabudowaniami istotne dla usytuowania planowanego przedsięwzięcia może być występowanie w podobnej odległości obiektu hodowli zwierząt futerkowych ze względu na zagrożenie występowania negatywnych skutków wpływu infradźwięków na zachowanie populacji tych zwierząt (Raport 2011: zał. 1). Jako uzasadnienie powyższej tezy 
można przytoczyć sytuację opisaną w niemieckim czasopiśmie „Die Welt am Sonntag", w artykule przedstawiającym wpływ infradźwięków na populację duńskich norek (Web-o2). W powyższym artykule wykazano, iż w duńskiej gminie Herning znajdującej się na Półwyspie Jutlandzkim, uruchomienie turbin wiatrowych po raz pierwszy spowodowało niepokojące w swych skutkach zachowanie hodowlanych norek na pobliskiej fermie zwierząt futerkowych. Dźwięk pochodzący z obracającej się turbiny wiatrowej przyczynił się do wywołania zjawiska szoku i obłędu u norek, w których zostały wzbudzone zachowania agresywne, co w afekcie doprowadziło do walk między zwierzętami i licznych zagryzień wśród wojujących ze sobą osobników. Zanim jednak nastąpiło to dramatyczne wydarzenie, zaobserwowano niepokojące odgłosy piszczenia norek tuż po uruchomieniu turbin wiatrowych. Wysoka śmiertelność tych zwierząt może znacząco wpłynąć na zyski i straty ekonomiczne hodowców zwierząt futerkowych. Jeżeli ten negatywny wpływ na zwierzęta przyczynił się do ich śmierci, zastanawiające może być również oddziaływanie farm wiatrowych na ludzką sferę psychofizyczną. Opierając się na dotychczasowych wywiadach ze społecznościami mieszkającymi w pobliskim sąsiedztwie elektrowni, wykazano, że lokalizacja farm wiatrowych w pobliżu miejsc zamieszkania może powodować problemy zdrowotne związane z bezsennością, apatią, nieustannym zmęczeniem psychicznym organizmu, problemami z zachowaniem koncentracji, a także może przyczynić się do wystąpienia chorób psychicznych i podwyższonego poziomu stresu. Opisane w powyższych przykładach badania zagranicznych naukowców dowodzą, iż ukazane przykłady negatywnych oddziaływań elektrowni wiatrowych na środowisko ludzi i zwierząt są wystarczającym dowodem, aby społeczności były pejoratywnie nastawione do aspektu ich budowy w sąsiedztwie domostw. Nie są to jedyne zagrożenia dla środowiska. Spośród pozostałych niebezpieczeństw, które mogą towarzyszyć eksploatacji siłowni wiatrowych, można wyróżnić także efekt stroboskopowy i efekt migotania cieni oślepiający ptaki.

Negatywne oddziaływanie elektrowni wiatrowych na środowisko dotyczy przede wszystkim wpływu na człowieka, jego zdrowie i samopoczucie, ale również zwierzęta odczuwają niekorzystne zmiany w środowisku. Zmienia się występowanie bioróżnorodności wśród zwierząt. Osobnikami najbardziej narażonymi na niebezpieczeństwa podczas pracy elektrowni wiatrowych są gatunki ptaków i nietoperzy, ponieważ bardzo często w okresie ptasich wędrówek wiosennych i jesiennych dostają się w śmigła wiatraków, a więc stają się ofiarami wypadków spowodowanych przez obracające się turbiny. Teren planowanych inwestycji farm wiatrowych będzie zlokalizowany w pobliżu obszarów chronionych, w bliskim sąsiedztwie obszarów Puszczy Białej wraz z obszarem chronionym Natura 200o. Ponadto teren inwestycyjny będzie sąsiadował z ostoją ptaków o znaczeniu europejskim Important Bird Areas - PLo58 Puszcza Biała, więc niezwykle istotne dla budowy i eksploatacji farm wiatrowych może być występowanie w ich pobliżu gatunków chronionych. Na podstawie analizy danych raportu o oddziaływaniu na środowisko Zespołu Elektrowni Wiatrowych "Podborze” i opracowania monitoringowego środowiska awifauny stwierdzono występowanie na danym obszarze 192 gatunków ptaków, w tym co najmniej 15 gatunków ptaków objętych ochroną gatunkową według Załącznika I Dyrektywy Ptasiej (79/409/EWG). Należą do nich: bocian czarny (Ciconia nigra), bocian biały (Ciconia ciconia), derkacz (Crex crex), lelek (Caprimulgus europaeus), kraska (Coracias garrulus), świergotek polny (Anthus campestris), trzmielojad (Pernis apivorus), błotniak stawowy (Circus aeruginosus), błotniak łąkowy (Circus pygargus), bielik (Haliaaetus albicilla), orlik krzykliwy (Aquila pomarina), żuraw (Grus grus), zimorodek (Alcedo atthis), dzięcioł średni (Dendrocopos medius) i lerka (Lullula arborea). Ponadto na danym obszarze stwierdza się także występowanie następujących 
gatunków ptaków przelotnych: czapli białej (Egretta alba), kani rudej (Milvus milvus), rybołowa (Pandion haliaetus), błotniaka zbożowego (Circus cyaneus), drzemlika (Falco columbarius), kobczyka (Falco vespertinus), kropiatki (Porzana porzana), siewki złotej (Pluvialis apricaria), biegusa zmiennego (Calidris alpina), łęczaka (Tringa glareola), bataliona (Philomachus pugnax), rybitwy rzecznej (Sterna hirundo), rybitwy białoczelnej (Sterna albifrons), włochatki (Aegolius funereus), sowy błotnej (Asio flammeus) i dzięcioła zielonosiwego (Picus canus). Wnioski z monitoringu dowodzą, iż planowana inwestycja nie będzie miała negatywnego oddziaływania na ptaki. Możliwe jest jednak wyższe ryzyko zagrożenia w okresie wiosennych i jesiennych ptasich wędrówek. Zlokalizowano także występowanie 4 gatunków ssaków: zająca (Lepus europaeus), sarny (Capreolus capreolus), jelenia europejskiego (Cervus elaphus elaphus) oraz lisa (Vulpes vulpes). Oprócz wyżej wymienionych zwierząt na podstawie monitoringu chipterologicznego stwierdza się także brak negatywnego oddziaływania na środowisko populacji nietoperzy (Chiroptera), z wyjątkiem zderzenia ze skrzydłem rotora lub śmierci będącej wynikiem barotraumy zlokalizowanych nietoperzy - borowca wielkiego (Nyctalus noctula) i mroczka późnego (Eptesicus serotinus) (Cieśluk et al 2011).

Planowane przedsięwzięcie nie będzie miało negatywnego oddziaływania na pozostałe obszary chronione, czyli Dolinę Dolnej Narwi i Dolinę Dolnego Bugu, oddalone odpowiednio o ok. $30 \mathrm{~km} \mathrm{i} 12 \mathrm{~km}$ od terenów inwestycyjnych (Cieśluk et al. 2011: 8). Niewykluczone są także zagrożenia związane z katastrofami budowlanymi na skutek awarii, uszkodzenia lub oderwania się części urządzeń znajdujących się w wyposażeniu wiatraków. Poza tym eksploatacja turbin wiatrowych może przyczynić się do występowania na danym obszarze promieniowania elektromagnetycznego, drgań oddziałujących negatywnie na gleby, zaburzenia krajobrazu, a także zmian klimatu lokalnego i mikroklimatu, chociaż wyniki raportu wykluczają ryzyko wymienionych zagrożeń.

\section{Przeciwdziałanie skutkom i działania profilaktyczne}

Chociaż nadal trwają spekulacje na temat realizacji planowanej inwestycji, w dokumentacji samorządowej nigdzie nie znaleziono wzmianki o rzeczywistym planie wdrożenia budowy przedsięwzięcia w najbliższych latach. Ciągle nie do końca wiadomo, czy na skutek wprowadzenia do polskiego prawa tzw. ustawy odległościowej (Ustawa 2016), znacznie ograniczającej lokalizację wiatraków w pobliżu zabudowy mieszkalnej, nie zaniechano zamierzonej budowy. Gdyby jednak doszło do realizacji planowanej inwestycji farm wiatrowych, należy rozważyć oraz wziąć pod uwagę prawdopodobieństwo powstałych w wyniku ich eksploatacji skutków opisanych powyżej i zastosować następujące działania profilaktyczne mające na celu przeciwdziałanie wyżej wymienionym skutkom.

W wyniku eksploatacji elektrowni wiatrowych powstaną duże ilości odpadów, w tym m.in. pochodzących z olejów smarowych użytych podczas okresowej konserwacji urządzeń. Aby zapobiec zanieczyszczeniom prowadzącym do zatrucia, a w konsekwencji do dewastacji i degradacji gleb, należy wdrożyć odpowiednie działania prawidłowego gospodarowania powstałymi na tym etapie odpadami. W przypadku powstałych odpadów eksploatacyjnych, do których należą mineralne oleje hydrauliczne i silnikowe, przekładniowe i smarowe oraz inne oleje, sorbenty, materiały filtracyjne, tkaniny przeznaczone do wycierania oraz ubrania ochronne zanieczyszczone materiałami niebezpiecznymi, należy przekazać je odbiorcy odpadów, a następnie odpowiednio zutylizować. Sposób właściwego postępowania z odpadami olejnymi został szczegółowo opisany w Rozporządzeniu Ministra Gospodarki z dnia 5 października $2015 \mathrm{r}$. w sprawie szczegółowego sposobu postępowania z olejami odpadowymi. W przypadku odpadów opakowaniowych, zawierających 
pozostałości substancji niebezpiecznych lub nimi zanieczyszczonych, należy wykorzystać je do przejściowego magazynowania lub również przekazać odbiorcy odpadów.

W ramach działań zapobiegawczych emisji hałasu i infradźwięków, w pobliżu zabudowań mieszkalnych i gospodarczych, należy zwiększyć odległość usytuowania elektrowni wiatrowych w stopniu niezagrażającym zdrowiu i samopoczuciu miejscowej ludności, gdyż z etycznego punktu widzenia oraz według przepisów polskiego prawa każdy obywatel ma prawo do życia w czystym środowisku. W tym celu warto, aby została znowelizowana ustawa o inwestycjach w zakresie elektrowni wiatrowych. Należy określić w niej dokładną odległość farm wiatrowych od zabudowań przy zastosowaniu dokładnych pomiarów dźwięku. Poza zmianami legislacyjnymi można też pomyśleć o wdrożeniu idei ustawienia ekranów akustycznych przy zabudowie mieszkaniowej sąsiadującej z elektrowniami wiatrowymi. Wówczas emisja hałasu i infradźwięków nie będzie w aż tak dużym stopniu zakłócała spokoju mieszkańców. Również w przypadku obiektu hodowli zwierząt futerkowych warto zastosować powyższe działania profilaktyczne lub przenieść hodowlę w inne bezpieczniejsze miejsce niezagrażające życiu tych zwierząt.

Na czas ptasich wędrówek w okresie wiosennym i jesiennym należy zaprzestać eksploatacji siłowni wiatrowych, minimalizując tym samym ryzyko wystąpienia zderzeń ptaków z rotorem. Na podstawie opracowania monitoringu awifauny R. Kozika i P. Cieśluka: „W celu uniknięcia wzrostu śmiertelności ptaków w okresie wiosennej migracji, należy w okresie 1-15 kwietnia całkowicie zrezygnować z uruchamiania turbin. W okresie jesiennej migracji okres unieruchomienia turbin powinien trwać od 10 września do 10 października" (Cieśluk et al. 2011: 45). „Aby zmniejszyć śmiertelność nietoperzy należy w okresie rozrodu od 1 czerwca do 15 września wstrzymać uruchamianie elektrowni” (Brzózka M., 2016).
Stosując zalecone powyżej działania zapobiegawcze, istnieje duża szansa na uniknięcie bolesnych dla środowiska skutków eksploatacji elektrowni wiatrowych. W drodze ewentualności można rozważyć ustawienie na danym terenie bezgłośnej turbiny Savonius'a (Boczar 2008: 174).

\section{Podsumowanie}

Reasumując, eksploatacja farm wiatrowych, poza korzyściami wynikającymi z produkcji energii elektrycznej i stałych dostaw prądu oraz dużych szans na zminimalizowanie kosztów dostaw energii, a także minimalizacji lokalnego bezrobocia na skutek stworzenia nieznacznych miejsc pracy dla miejscowej ludności, stwarza wiele problemów natury społeczno-gospodarczej. Obecnie, wielu mieszkańców żyjących już w sąsiedztwie wybudowanych elektrowni wiatrowych skarży się na negatywne skutki ich oddziaływania na zdrowie, warunki życiowe i samopoczucie. Trudności pojawiają się również w aspekcie prawnym, techniczno-technologicznym, edukacyjnym oraz ekonomicznym, związanym z nieustannie wysokimi kosztami inwestycyjnymi (Jastrzębska 2007: 45). Planowany projekt siłowni wiatrowych bardzo często staje się przyczyną starć i może zwiększyć ryzyko występowania konfliktów społecznych, mających związek z realizacją przedsięwzięcia. Licznym zagrożeniom może ulec środowisko przyrodnicze narażone na negatywne oddziaływania eksploatacyjne. Podsumowując, świadomość ekologiczna społeczności lokalnych nadal jest niewielka, a aktualny stan projektów inwestycyjnych nie rokuje pozytywnie na spokojną ekologiczną przyszłość mieszkańców okolic Ostrowi Mazowieckiej.

\section{Bibliografia}

Boczar T., 2008, Energetyka wiatrowa. Aktualne możliwości wykorzystania, Wyd. PAK, Warszawa. Bronzaft A.L., 2011, The Noise from Wind Turbines: Potential Adverse Impacts of Children's Well-Being, Bulletin of Science Technology \& Society, 31, 291-294. 
Brzózka M., 2016, Analiza i aspekty konsumpcji energii $z$ wykorzystaniem odnawialnych źródet energii w gospodarstwach na terenie gmin Andrzejewo i Ostrów Mazowiecka, praca magisterska UKSW, Warszawa.

Cieśluk P., Kozik R., 2011, Ocena oddziatywania planowanej farmy wiatrowej na środowisko ze szczególnym uwzględnieniem awifauny, w gminie Ostrów Mazowiecka, z lokalizacja pomiędzy miejscowościami Podborze, Ugniewo, Ostrów Mazowiecka, Mazowiecko-Świętokrzyskie Towarzystwo Ornitologiczne.

Hopkin S.P., Peakall D.B., Sibly R.M., Walker C.H., 2002, Podstawy Ekotoksykologii, Wyd. Naukowe PWN, Warszawa.

Jastrzębska G., 2007, Odnawialne źródta energii i pojazdy proekologiczne, Wyd. Naukowo-Techniczne, Warszawa.

Plan Gospodarki Niskoemisyjnej dla gminy Ostrów Mazowiecka, Ostrów Mazowiecka, lipiec 2015.

Raport o oddziaływaniu na środowisko Zespołu Elektrowni Wiatrowych „Podborze” z infrastrukturą techniczną (gm. Ostrów Mazowiecka, pow. ostrowski, woj. mazowieckie), Biuro Projektów i Wdrożeń proekologicznych „PROEKO”, Gdańsk, wrzesień 2011.

Rozporządzenie Ministra Gospodarki z dnia 5 października 2015 r. w sprawie szczegółowego sposobu postępowania z olejami odpadowymi (Dz.U. 2015, poz. 1694).

Rozporządzenie Ministra Klimatu z dnia 2 stycznia 2020 r. w sprawie katalogu odpadów (Dz. U. 2020 r. poz. 10).

Ustawa z dnia 20 maja $2016 \mathrm{r}$. o inwestycjach w zakresie elektrowni wiatrowych (Dz. U. 2019 r. poz. 654, ze zm.).

Van den Berg G.P., 2004, Effects of the wind profile at night on wind turbine sound, Journal of Sound and Vibration, 277, 955-970.

(Web-o1) http://e-czytelnia.abrys.pl/recykling/ 2005-2-157/recykling-odpadow-1309/trendy-w-recyklingu-olejow-odpadowych-w-ue-4579 (dostęp: 5.04.2018).

(Web-o2) http://hd.welt.de/wams-hd/wams-hd_wirtschaft/article137896681/Wenn-Windkraft-krank-macht.html (dostęp: 6.04.2018).

\section{Environmental conditions of the construction and operation of wind farms "Podborze" near Ostrów Mazowiecka}

\section{Abstract}

The article presents selected issues related to the construction and operation of wind farms. The case study concerns the planned wind farms "Podborze" near Ostrów Mazowiecka. Potential ranges and effects of the planned investment will be indicated. The last element will be indicating ways to preventive measures and counteracting negative effects.

\section{Keywords}

wind farms, renewable energy sources, impact, environmental aspect 